\title{
OUTLOOK
}

\section{JANUS-FACED STATE AND SOCIETY: TRANSITIONS IN UKRAINE}

\author{
Éva PERPÉK \\ Ph.D-Student, Budapesti Corvinus Egyetem, Szociológia és Társadalompolitika Intézet \\ H-1093 Budapest, Fővám tér 8.; e-mail: eva.perpek@yahoo.com
}

\begin{abstract}
This study focuses on the social structural approach of the reforms in Central and Eastern European countries based on the material of an international conference held in Kiev. In the fist part, we outline the role of elites, classes and civil society both during the system change and after that. Supporting David Lane's approach we define the terms of administrative, capital and global political classes. In the second part, we examine the developments during the recent twenty years in Ukraine since its independence. This period has a double character: we see West-European democratic ideas and institutes implemented in traditional Soviet mentality and practice. We analyze the successful initiatives of the country striving for independency and the double characteristic institute system built on the above-mentioned dichotomy. We lay special attention to the orange revolution, considered as the most important reform by public opinion, in reality being only a swing towards building democracy. In the third part, we leave the macro-social analytical frames behind and describe the Parliament of Ukraine from inside. Our first impression of an ambiguously complex party system becomes transparent as a result of applying the social network analysis. Based on examining the structure of the legislative body, we discover the development of relationships and dynamics among the political parties, groups and fractions during the four (!) significant structural reforms in the concerned period.
\end{abstract}

Keywords: Post-communist countries, regime change, stratification, class, elite, double institutional system, Orange Revolution, Parliament of Ukraine, social network analysies

On 18th and 19th of May 2006 the Institute of Sociology of the Ukrainian Academy hosted a conference on examining the societies' transitions in Central and Eastern Europe. The conference, initiated by David Lane (University of Cambridge) titled: The role of the classes, the elite and the community in the transition of the Ukrainian society ${ }^{1}$ was organised with the aim of providing a professional forum to the Ukrainian, Russian and foreign researchers to make comparison in space and time.

1 The original title of the conference: Rol' klassov, yelit, obschestvennosti v social'nyh transformaciyah $v$ Ukraine. 
Documentation of the conference was published in a special issue of the Ukrainian periodical called Sociology. The three separate sections of the conference were the Classes, the Elites and the Community. In his keynote speech David Lane underlined the general role of the elites, the classes and civil society in the transition of the Central and Eastern European region. In the second comprehensive plenary lecture Ukrainian co-authors (Golovakha and Panina) provided thorough analysis of the social procedures of 20 years of the Ukrainian transition from many aspects.

In my interpretation these two studies are the pivots of the conference as the article of Lane deepens our knowledge on societies under political system transition in general, while the work of Panina and Golovakha provides detailed information on the specific aspects of the transition of Ukraine on the one hand and the common features of other Central and Eastern European societies on the other. Further to these two studies there is a third one analyzing the social network of the Ukrainian Parliament that is worth noticing. In this study, the authors Gorbachik and Zhulkevskaya focus on the structure of the relationships of the members of parliament (MPs) as well as on the changes there between 2002 and 2006.

\section{CLASS ON THIS SIDE - GROUP ON THE OTHER? ELITES, CLASSES AND CIVIL SOCIETY IN THE POST-SOCIALIST STATES}

The name of David Lane sounds familiar to structure researchers. For instance, his book published together with Cameron Ross in 1999 gives detailed information on Soviet and post-soviet elites, their functions in starting the political transition and their role in controlling independent Russia. In their important work Lane and Ross primarily examine the career of the elites through different documents and interviews. Focusing on the biggest successor state they emphasize that during the political transition the so-called administrative or executive capital played a more important role than the political one. This book pays special attention to analyzing the different segments of the political elites such as the government bureaucracy, the members of the Central Committee or the initially converging, later diverging Supreme Council.

At the beginning of his lecture at the conference Lane (2006), anticipating the most important thoughts, mentioned that the main explanatory variables of the socialist transition are generally depicted by the reproduction and the circulation of the elites. Regarding the capitalist class during state socialism only a weak version of that could be built up because of the undeveloped civil society. Lane holds the view that this latter one could not develop because of the barely existing (professional) civil class. The group of the society that advanced the move toward the market and privatization during the Soviet era was the political elite who were "playing" both on the national and the international "stage". In the post-Soviet era the social disparity and the tension within the society increased while the fast economic and political transition weakened the improvement of the consciousness of the opposite class.

Before presenting his views Lane provided an overview of the social transition theories considered to be relevant by him. Among others he touched upon the Kullberg-Higley-Pakulski elite theory which explains the transition from state 
socialism to capitalism as the agreement of the elites. The author, continuing the conception of Highley and Pakulski (1995), describes that the members of the elite developed a strong formal ideological consensus while they had real disagreements regarding specific political issues.

At this point Lane gets to that crucial question of why do the political elites who carry out the post-communist reforms accept unanimously the ideology and logic of the market, private ownership and multiparty system? In his opinion the class base approach and principally not the elite paradigm (e.g. Higley) can give an appropriate answer. The remaining part of the study focuses on this explanation. As a criticism the researcher underlines that when it came to the inspection of the social changes the class as explanatory variable practically vanished at the end of the 20th century, therefore the expression is not present in the researches carried out on transition.

When the author determines the interests of the classes he specifies the meaning of the expressions like: social, administrative, acquisition and global political class. Social class is defined as a group of individuals with different life chances in terms of market and ownership conditions. Administrative class on the one side consists of the leaders of productive institutions (economic ministries, international commissions, big companies) and organizations providing replacement (institutions of higher education, scientific centres) on the other. Initially this class - similarly to the Chinese model supported such a transition in which the co-ordination of the economy would have been controlled by the state machinery and the communist party. Latent extremist members of the administrative class urged to weaken the central controlling-planning as well as the Soviet state itself. Most of the Central European countries, including Poland, shared the same view. Knowing these the question of Lane is well-founded: in case this group was latent who did actually initiate the radical reforms?

To answer this question Lane invokes the citizenship of Mandel that the researcher calls acquisition class ${ }^{2}$. Its members have two features: qualification and professional skills. The acquisition class furthers the bourgeois redistribution of the resources, namely increases their property which also supports the transition to the market economy. They strongly maintained the civil society, a critical platform and re-privatization of the political institutions. Gorbachev himself advocated this policy in the first years of the reforms. In the early stage of the political transition administrative and acquisition classes supported shoulder to shoulder the market; however, they were not for the privatization of state property. In $199070 \%$ of the state officials and the party leaders in the Supreme Council and more than $80 \%$ of the MPs, former leaders and the professional intellectuals supported the market. However, when it came to the questions of privatization and private ownership, $70 \%$ of the political elite and $40 \%$ of the professional intellectuals voted against these issues.

Drawing the foreign capital into the analysis the author starts to introduce the term global political class. As it is well known, in the socialist countries the role of the transnational companies was quite low; by the middle of the eighties we hardly find any relevant foreign investment. As he writes: "The capitalist companies formed a

2 Namely: “...position composed of people seeking a system based on private property and markets. This group we define as an 'acquisition class' ... ." (Lane and Ross 1999: 19). In Russian translation: priobretayuchiy klass. This practically covers the middle class or citizens. 
unique island in the ocean of central planning." (Lane 2006: 22) ${ }^{3}$ In the Soviet Union foreign companies like Pepsi Cola or Fiat could operate under strong state control, the number of the companies owned by foreigner owners was limited. Liberalization of the economy was carried out when Gorbachev was the secretary of the party, though this liberalization was not too efficient, under different rules the establishment of companies with domestic foreign ownership was allowed, economic zones were made. Lane supports the difficult implementation by the following data: in 1989 only 23 foreign-domestic joint ownership companies existed in the Soviet Union. Due to the economic policy of the perestroika this number was 1572 in 1990, however, in spite of the considerable nominal increase the volume of the investments was not high, the only considerable investor was Fiat by investing 1 billion dollars.

In addition to the economic sphere, by involving the social segment Lane underlines: "Societies of the state socialism were considered to be half-periphery in the capitalist states." (Lane 2006: 22). The transnational capitalist class was unable to exist as it really is, there were no latent representatives of international capital in the socialist countries, and therefore the new reigning capitalist class could not develop. However, the relationship of the domestic political and economic elite with each other on the one hand and their relationship with the international elite on the other were such external impulses that induced the change of the social system. After that the researcher shows the response given by the state to these challenges.

Lane differentiates between the two functions of the state. The first one was within the scope of the national economy where the state is an instrument of the capitalist class hegemony; the second one is toward the world where the state protects the interests of national capital. Which of them comes into the limelight is determined by fact that the state would like to enforce its national or international interest. Here we come to a crucial point of the study where the author underlines that transition to the market economy and the commencement of privatization was initiated, supported by the international political elites. ${ }^{4}$ In his opinion the promoter of the changes was not the global capitalist class, but the alliance between the political elites, but that alliance was quite difficult to reveal. There was an internal agreement between Gorbachev and Shevarnadze and also the representatives of the external political elite - George Bush, Helmut Kohl, Bill Clinton, Margaret Thatcher, allied with each other too. In the interpretation of Lane the global political elite (not class!) that plays an important role is the group of people who make the global political-economic strategy. They are the international state and non-state organizations (CIA, IMF), globalization-oriented politicians and leaders ${ }^{5}$.

In the following part of his study Lane names the international political elite institutions that initiated the capitalist transition and managed the domestic economic and social policy changes. These institutions were the IMF, the European Union and

3 We may not handle the socialist countries as a uniform block. In order to sophisticate the view Lane mentions a Hungarian example where foreign capital already entered the country at the beginning of the seventies, similarly to Poland

4 At this point Lane reminds us not to mix up the global political elites which launched the changes with the global capitalist class.

5 As an example there appears a footnote on the participants of the Davos Conference.

Review of Sociology 14 (2008) 
the Council of Europe. Their aim was to introduce a multiparty political system and neo-conservative economic policy primarily in those post-socialist countries that wanted to accede to the EU. As a result in June 1993 the Copenhagen criteria expressing the interest of the global capitalist class were agreed upon.

The last part of the study is about the support of the transition by the societies. To enter into detail the author first mentions civil society that consists of two spheres. On the first, economic level there are such business associations that are established by private owners in order to make profit. As a social class there is the bourgeoisie behind it. By Lane the second class consists of the social and political organizations such as civil organizations, parties. This is the platform where criticism and protest against the state can be expressed. Lane underlines that not unknown fact that civil society in the post-socialist countries is weak regarding both of these features. Since no bourgeoisie existed during state socialism, they were unable to organize themselves into a specific class. Regarding Russia and Ukraine he underlined: capitalism has not developed in these countries, for the time being the development is still "guarded" by the state ${ }^{6}$. After the socialist era, it was not really successful to form the top controlled civil society that was supported by the West. Taking specific data, Lane demonstrates that with the exception of the trade unions, the number of all civil organizations' members remained quite low. Members of the organizations related to human rights and the problems of the third world are just a low percentage of the average of the Western countries, and lags behind the average of the new EU countries. ${ }^{7}$

When it comes to transition we speak about winners and losers - reminds the author. The new acquisition class gained considerable advantage, while the blue-collar workers and peasants lost so much. The intelligentsia cannot be squarely put under either of the categories. Approach to the reforms is a question of class and time. Members of the administrative class make profit on it, while the role of those belonging to the acquisition class as well as the intelligentsia is dual. Those who were against the reforms in the post-communist countries belong to lower classes, the old and the ones with lower levels of education. In the countries that changed their political system such self-organizing activities that concern the whole country are rare, there is no permanent and wide social base of these initiatives. Having made a comparison Lane mentions that while in the Western countries the key for stability is the strong civil society, the post-socialist countries can be described by such stability that is result of the agreement of the elites.

Summarizing the lecture the following can be stated. The Central and Eastern European transitions can rather be called transformation than revolution, since there were no essential specifications like violence, charismatic leaders, ideological basis and the power of the propertied involved. The best supporters of capitalist transition are the holders and the administrative class. The activity of both groups was determined by the political culture of state socialism, they were unable to communicate their ideology clearly. Capitalism was created centrally, from the top,

6 The determining and revolving role of the state is reinforced by the re-nationalization of the major Russian oil companies.

7 Here Lane made reference to the findings of the European Values Study of 1999-2000 and the 2004 European Social Survey. 
transnational companies took part in developing the capitalist ideology, institutions and procedures. Lane shows the strengths and weaknesses of the political transition. As a weak point he mentions that the "immaturity" of the civil society revived the pact of the political elites. In the new EU Member States the capitalist class could become stronger since in these societies "the capitalist class took root prior to the Soviet era" (Lane 2006: 30). On the contrary, state socialism in the Soviet Union - with the exception of the Baltic States - was stronger; it had a domestic revolution base and a less homogeneous elite. Therefore the reach of the so-called elite pact was more complicated. The strong reforms of Gorbachev required external, foreign economic assistance. The weakness of the civil society generated the development of the bourgeoisie; members thereof knew how to get capital while their political knowledge was incomplete. Lane's closing words underline that post-socialist transition can not be considered to be over and further political system transition movements are expected in the Eastern part of Europe.

While reading the study we can be convinced on the competence and researching experience of David Lane. He makes reference to numerous theories and empirical research findings - including his results - creating the impression that he can see this field from above. He investigates the transition process of the Central and East-European countries, putting the Soviet Union into the spotlight. In some cases he emphasizes the characteristic of certain states (for instance, in case of Hungary and Poland), but in most cases he speaks about the countries in general, without making any differentiation among them. Sometimes it seems to be a bit too generalized. The way he applies the expressions shows that the author considers these countries uniformly as he uses the expression of post-communist countries, sometimes replacing it by the post-socialist adjective. But we are used to the fact the post-communist label is used - especially by foreign authors - to all of the Central and East-European countries, for the sake of order we must note that this attribute cannot be used regarding the Central European or Baltic States. Nevertheless, on the whole this is a quite nice, diversified, balanced style of study that represents the author's own views.

\section{THE CENTAUR STATE. UKRAINE FROM PERESTROIKA TO THE ORANGE REVOLUTION}

Golovakha and Panina (2006) estimate the length of the social transition to last for about 20 years from the nomenclature of Gorbachev to the Orange Revolution. From this era there are plenty of data regarding the changes that happened concerning the Ukrainian society. ${ }^{8}$ This article summarizes concisely the findings of these researches. The authors display the actual status of the society in chronological order, starting with perestroika and the political change of 1991: the period when the nation became independent. The researchers picked up three components of the stable institutional

8 They carried out several data recording in relation to several foreign projects. The co-operating countries are the following: Hungary (Simon J., Bruszt L.), USA: 1991-1992, Switzerland: 1992-1994, USA: 1993-1996, France: 1994-1997, USA: 1996-2005, Russia: 1998-2006, Poland: 2001-2004.

Review of Sociology 14 (2008) 
system of this time: the lawmakers' base that ensures the social institutions, the institutional infrastructure that enmeshes everything and the fact that most of the inhabitants accept the so-called Soviet lifestyle. Golovakha and Panina underlined that the former Soviet Union was not ready for transition at all, and its signs can be seen in all of the successor countries, with the exception of the Baltic States. For instance, the GDP of these countries which became independent does not reach the level of the former Soviet Union, the political leaders are authoritarian and this is accepted by the society.

They raised the question of what was the motive of the significant social changes. In their response they indicated two main factors, however, these causes were not the regular reasons (international economic interests, war in Afghanistan, strive for national independence): Gorbachev came into power and there was the Chernobyl catastrophe. The appearance of young leaders' group was expected after the long period of gerontocracy and this caused that the totalitarian ideology supporting the state was questioned. While the nuclear explosion put such fatal danger into the spotlight what irresponsible people controlling such technology may cause to the society.

The collapse of the institutions was supported by three further factors: pressure of the West, endeavor for independence of the socialist-block countries, and the burdens of subsidy granted to the anti-Western third world that put the pressure on the Soviet economy. Going back to the findings of the researches carried out in the seventies they remarked that the need for high social status resulted in dissatisfaction with the social system among the young, dynamic workers entering the labor market. Because a huge number of them wanted to be given such positions that would have placed them at a higher level of the social hierarchy. Therefore the leaders of the Soviet Union should let some social-economic freedom to the ambitious cohorts. From the other side the authors believe that this way did not attract the talented intelligentsia, who played an important role in the political transition according to David Lane as well.

The researchers continue with the unique role of Ukraine emphasizing that the post-communist transition caused damage to practically all the social institutions, demolishing such institutions that guaranteed the social order like legality and organizational infrastructure. At the same time signs of the legal order appeared, including presidential power, multiparty system, private ownership, and private companies. The new legitimate institutional infrastructure appeared and paradoxically it did not embody the norms of the democratic society. As they wrote "... Ukraine was ready to demolish the old institutional system just as it was not prepared to build up the new ones" (Golovakha and Panina 2006: 37).

The second part of the study is about the period 1992-1994. At a first sight one may think that the institutional system necessary to launch the democratic market economy in Ukraine was made by the beginning of 1992. Moreover, a unique Ukrainian model was developed that is different from the Baltic, Russian, Caucasian and Central Asian ones. Similarly to the Byelorussian and Kazakh structure this is a 'half-open' or 'closed-open' society where the economy is controlled by the state, but slowly it is vested with signs of the market. It is easy to understand that this 'political-economic centaur' could not live for long time. In the first phase of the transition most of the 
population was under the poverty threshold and people were fighting for physical survival. However, this model was sustainable as the different political forces did not confront, there were no revolts, no carnages; therefore President Leonid Kravchuk could regard his internal policy to be successful. The majority of the population candidly supported the democratic institutional system and the market economy while indeed they lived in accordance with the principles of the former political system.

We must touch the role of the diversified political elite at the beginning of the transition. As a result thereof the political elite were split up as the party in power and the opposition. Following the change of the political system there evolved a dispute on the one hand between the former and the new elites as well as between the society and the elite and these caused tension in the post-totalitarian society. The former leaders preserved their economic power and the new elite hold the ideological power in their hands as power was based on the independence of the nation state. The roughly dozen parties declared themselves to be opposition parties but were unable to act as real opposition parties, while the party in power easily sacrificed its ideology and its own individual political character.

The third period of independent Ukraine was between 1994 and 1998, when a double institutional system was developed. In the first years of independence practically no new legitimate institutions were introduced in Ukraine, rather the former leaders renewed themselves and acted without any financial, prestige or moral losses. The political phenomenon called centaur means that on the level of intentions Ukraine turns its head to the West while its body behaves in accordance with the spirit of socialism. Here below the period of reaching national independence is compared with the period of the double institutional system in a demonstrative manner:

The authors return to the question of what was the reason that the Ukrainian society had avoided the 'second comeback of the communist messiah'? They explained it with the following: the Soviet social institutions lost their legality but kept their traditional legitimacy. As people accepted, for instance the state-owned big companies also education, healthcare, science and arts continued to be managed by the state. On the other hand the Soviet black market solutions, the double morals and the corruption were filtered into the legitimate institutions of the new, transitional society. Therefore wide segments of the society felt ambivalent regarding the emerging old-new order. This is called by the authors as the 'hyper full-value of institutions.' The classic sample is the members of the Ukrainian Parliament who were active at the same time in the economic and political life. These social processes embedded in a worsening economic situation combined with degreasing GDP, high unemployment rate, decreasing standard of living, pessimistic mood of people, dissatisfaction with the present and uncertainty regarding the future. However, in this manner the country progressed ahead at a snail's pace. Since the Constitution was enacted, wide range of privatization procedures was launched ${ }^{9}$ and a new national currency was introduced.

9 The process can really be considered to be successful, as by 1998 most of the companies were privatized - as it is emphasized by Panina and his co-author.

Review of Sociology 14 (2008) 
Table 1. Ukraine during the Period of reaching the National Independence and the Double Institutional System

\begin{tabular}{|c|c|c|}
\hline Features ${ }^{10}$ & $\begin{array}{c}\text { 1991-early 1992 } \\
\text { National independence }\end{array}$ & $\begin{array}{c}\text { 1994-1998 } \\
\text { Double institutional system }\end{array}$ \\
\hline Economic orientation & $\begin{array}{c}\text { Economy is regulated by } \\
\text { market mechanism }\end{array}$ & $\begin{array}{c}\text { Producers' sector is supported } \\
\text { by the state }\end{array}$ \\
\hline Support by the society & $\begin{array}{c}\text { Independence of the state is } \\
\text { supported by the majority of } \\
\text { society }\end{array}$ & Support of t reintegration \\
\hline Role of the communist party & Lost its social mass base & $\begin{array}{c}\text { The main opposition party } \\
\text { would like to get the power }\end{array}$ \\
\hline Responsibility & $\begin{array}{c}\text { Communist party was blamed } \\
\text { for the crisis }\end{array}$ & $\begin{array}{c}\text { The democratically elected } \\
\text { power is responsible }\end{array}$ \\
\hline
\end{tabular}

The next part of the study focuses on the period of 1999-2004, in which stage a new institutional crisis developed and which was ended by the Orange Revolution. The first presidential term of Leonid Kuchma that commenced in 1994, was featured by political stability and economic difficulties, while the second one by economic growth and political storms. In Golovakha's and Panina's opinion the anti-Kuchma feeling of the society was stemming from the contradiction between the institutional system and the expectations of the active segments of the society and the interest of the political elite of the opposition. The first attack against Kuchma in 2001 failed as the President was practically kept in his position by the double institutional system. Further on, in spite of the slow advancement of economic indicators most people were focusing on their own living, they did not have time and interest to take care of high politics. The standard of living increased by 2004, and people - looking out from their day-to-day problems - wanted to put an end to the Kuchma-era. By this time the effects of the double system's infrastructural and normative overload were felt by the people that made the society feel desolate and dissatisfied with their social position. The society found response to their emotions in the slogans of the opposition: "Bandits, to the prison!" "Power shall be separated from business".

After this the researchers continue concisely with the Orange Revolution. First they underline that in accordance with a survey carried out shortly after the revolution a strong democratization of the common knowledge took place. In other words, trust in the president of the republic, the government, the multiparty system and the leaders increased and respondents were convinced that the average people may have influence on the political processes of the country; they depicted a positive future of the state. A year later, just after the elections of April 2006, researches measured a lower level of democratization; therefore in their opinion the feeling in 2005 was just an oscillation toward democracy. Expectations of the revolution were cracked by reality.

In the last part of their study the authors examine the effect of the Orange Revolution on the society in the light of the surveys carried out since. Golovakha and

10 The study originally contained the right column of the chart the system of aspects would be own supplement. 
Panina focus on the striking change of mood within a year. While in 2005 the state of mind of people could be described by optimism, hope, joy and satisfaction, a year later the expressions are restlessness, fear, and pessimism. Moreover, opinion about the state institutions and political leaders became worse, respect for the institution of the president, executive power and the multiparty and representative systems decreased. The authors believe that people were disappointed both with the president of the state and the leaders of the revolution. The latter were supported by $15 \%$ of the respondents; next they became alienated from these leaders. Falling of support of the revolutionary powers is attributable to the fact that the leaders of the resolution, despite their promises made earlier, were not able to clear, for instance the political life, did not act against the economic abuses of the previous leadership (Ludvig 2007). Selective social memory is shown by the finding that in the year of 2006 a further 10 per cent of those questioned told - compared to the survey made a year ago -that they had never supported the Orange Revolution. Within a year the number of those tripled who felt themselves losers of the revolution.

Then authors create the impression that the public in Ukraine moved toward the 'Eastern geopolitical vector', and the number of those against NATO accession increased. It is somewhat controversial bit that at the same time people do support the EU accession of Ukraine. ${ }^{11}$ Two fifths of the people seem to be committed toward double directions: they consider acceptable to approach both the West and Russia. The authors draw the attention to another contradiction: the geopolitical orientation is not in accordance with the party preference of the respondents as well as the program of the supported party. The change of the mood of the people in 2006 is attributable to the dissatisfaction of the people: they were disappointed in the new power, after the revolution they did not get everything and immediately what they had expected. This disappointment does exist in the heart of the people despite the fact that their financial situation became better most recently. ${ }^{12}$ On the other hand, the authors are not satisfied with the explanation of disappointment; in their opinion the real reasons must be deeper. From their point of view the Ukrainian society lives in a vacuum of values: the old system of values is dissolved but the new democratic principles have not yet developed. This norm and value basis that indicates what is good and what is bad, what is to be punished and what is to be rewarded is missing. These circumstances brought most members of the society into the phase of the 'loss of values without norms'. Consequently the community tries to reorganize the social order based on traditional values. This is felt by those who get power as they appreciate the archaic values or try to make religion part of the state system of education.

Closing their article, Golovakha and Panina underline that the Orange Revolution that calls itself a democratic revolution is at the same time a cultural-ethnic revolution. They hold the view that historical identity is a very important aspect when it comes to the survey of the post-revolutionary social system. This historical memory divides Ukraine into numerous geographical parts: while the western part of the country would like to get out of the influence of Russia and Eastern Ukraine feels a social-cultural

11 In 2006 it was $61 \%$, at the same time the Russian-Ukrainian-Belarus union was supported by $64 \%$ of respondents.

12 As it was told by those questioned their salary, pension or bursary increased by $45 \%$.

Review of Sociology 14 (2008) 
unity with Russia, the Centre tries to balance between the two. Central Ukraine is in the stage of the double hesitation and rather prefers the West. The authors point out the responsibility of the political elite: it is impossible to put a country on the basis of democracy if even those leading the country violate the law. They believe that the leaders of the country must see to it that the laws are consistently followed and they shall persuade the society about it by their personal example.

The researchers started a major enterprise when they decided to summarize the political-social events and their effects on Ukraine in the last 15-20 years. I think that their undertaking was successful. The article provides lot of knowledge to the reader, exciting both to the researchers and to the public. Besides the amusing language of the article it has a negative effect: they use many picturesque and literary metaphors that increase the level of the article, but, however make the paper more difficult to understand and to get the scholarly findings. There are extremely long trains of thoughts in the article, one may feel that very often they do not only communicate data but use the game of the words in the text. This is quite amusing, but less informative. From this point of view chapter four of the study is different: in this part the authors focus rather on the bottom-line.

The level of the study is increased by the fact that the authors apply new, effective expressions. Expressions like political-economic centaur institutions, centaur state, second return of the communist messiah, hyper full-value of institutions. Nevertheless, this is a realistic study containing lots of empirical data; the low number of literature quoted can be mentioned as a problem. At the beginning of the study the list of researches, findings used by them, is contained 'in bulk' but the main part of the study quite rarely makes reference to any domestic or foreign researchers and researches. Reference by name is applied in the study only three times when Lane, Inglehardt and Sereda are mentioned. The quotation of empirical data is unbalanced in the study. In the first part of the article practically there are no research findings; however, the second part contains plenty of percentage share data. Compared to it the article of David Lane is much more balanced and the author was not sparing with the references. Taking into consideration these critical remarks this is a very important, high-toned, comprehensive study showing the Ukrainian society from many aspects.

\section{LOYALTY OR DISLOYALTY? DYNAMICS OF THE RELATIONSHIPS IN THE PARLIAMENT OF UKRAINE}

In the recent years we have been used to the fact that the Ukrainian political and public life is loud with tough quarrels: privatization scandals, the parliament turned against the president, government crisis, parliamentary elections earlier than scheduled, difficulties of forming the new government. In addition to the actual disputes - as it was already mentioned above - both the political elite and the public are divided, the general feeling is marked by duality: to stay in the pull of Russia or to be committed to the West. On the scene of high politics this dilemma seemed to be outlined regarding the questions like the natural gas supply of Ukraine, the United 
Economic Area, WTO membership and NATO accession (Ludvig 2006). In the Ukrainian party politics - summarizing the question in a nutshell - the two 'orange' parties (President Viktor Yuschenko and the Our Ukraine and Yulia Tymoshenko's Block) would like to reinforce connections with the West, while they try to put Russia into the shade; on the other hand Viktor Yanukovich, the former president, leader of the Party of Regions, making use of his close Eastern connections would pursue a pro-Russia politics. The only main question in which the three parties - Our Ukraine, Party of Regions and Yulia Tymoshenko Block - agree is that all of them support Ukraine's EU accession; and this is also supported by the majority of the society (Golovakha and Panina 2006). The country is divided as it is reflected by the behavior of the voters. For instance, let us take the elections at the end of 2004, the voters of the two politicians made an East-West and a Ukrainian-Russian imaginary language divide within the country: while the Western regions - like Lvov, Ivano-Frankovsk, Vinnica, Zhitomir and the Russian-speaking centrally located Kyiv - voted for Yuschenko, the regions of the east - Lugansk, Donetsk, Dnepropetrovsk, Kharkov, Krim - voted for Yanukovich.

In the spring of 2006 parliamentary elections were held in the country and carried out in accordance with the law. However, some months later it turned out that the president and the government cannot work together. The long lasting political crisis was planned to be eliminated at by-elections scheduled to be on 30 September 2007. After 4 months of negotiations the new government was formed, and the parties agreed upon the Prime Minister. However, co-operation of Our Ukraine and Tymoshenko Block in the government lacked a stable foundation. The permanent political uncertainty and the considerable amount spent by the government on social purposes had a negative result, for instance in 2006 the growth of the GDP dropped ${ }^{13}$. At the same time some positive changes took place in the economy. Ukraine is one of the most dynamically developing countries of the region, the interest of foreign investors has increased, inflation rate decreased, unemployment rate went down and the fight against black economy has been continuing successfully (Ludvig 2007).

As we know, the Ukrainian political groups and political parties are quite diversified. For example, in 1998 49, in 2002 62, in 2006 45, while in the by-elections in 200720 parties and blocks participated in the parliamentary elections. In accordance with the amendment of the Constitution ${ }^{14}$ as from 2006 all 450 MPs are elected from the list of the parties. The fact that prime ministers are changed in Ukraine quite often underlines that political life is active and unstable: in the last 20 years there were 18 prime ministers. Three of them were in this position twice: Vitaly Masol, Viktor

13 In order to be precise we should add the fact that different sources (OECD, WB, Ministry of Finance of Ukraine) provide different data on the GDP. For instance, according to the Ministry of Foreign Affairs of Ukraine GDP growth was $7.1 \%$ in $2006,10.8 \%$ in 2004 and $9.3 \%$ in 2003 . As forecasted by the World Bank the growth rate in 2008 is expected to be $5.5 \%$ whilst the recent economic crisis may modify this forecast.

14 The Parliament of Ukraine, officially called Verkhovna Rada Ukrainy (Supreme Committee of Ukraine) - enacted the Constitution on 26 June 1996, which was considerably amended on 8 December 2004. As a result of the amendment of 2006 a semi-presidential system was introduced in Ukraine (Fedinec 2007).

Review of Sociology 14 (2008) 
Yanukovich and Yulia Tymoshenko ${ }^{15}$. Continuity is secured by the institution of the president of the republic. For the longest period Leonid Kuchma was in this position: he was president for 11 years between 1994 and 2005. All of the presidents were in other state positions before the presidency: Leonid Kravchuk was the speaker parliament for one and half years before he became the president in 1991, Leonid Kuchma was prime minister for nearly a year in 1992-1993, while the current president, Viktor Yuschenko was the prime minister for one and half years from 1999 on.

After this general introduction let us continue with those discussed in the section called Elites of the conference. Gorbachik and Zhulkevskaya (2006) examine the structure of the Verkhovna Rada and the changes thereof by applying the social network analysis during the fourth term of Parliament between 2002 and $2006 .{ }^{16}$ They grab the connection of the political and informal groups by examining the cases when an MP crosses over from one political group to another, suggesting that when a representative in the Parliament joins another political group it makes connection between the political groups involved. The change of the political group can be done directly (from A to B) or indirectly, when a person first gets into another political group or informal group then joins the third one (from $\mathrm{A}$ to $\mathrm{C}$, then from $\mathrm{C}$ to $\mathrm{B}$ ). $\mathrm{By}$ the authors, the connection between the two groups involved is stronger, the structural units know each other better, and a bigger number of the transactions take place between them.

As we have mentioned, Gorbachik and Zhulkevskaya's survey covers the fourth term, when Vladimir Litvin was the Speaker of the parliament. The vividness of the fractions, parties and political groups referred above is proven by the data that there were 37 political groups and parties - existing for shorter or longer term - in the factions during the four-year term. By March 2006 the previous high number of parties was normalized but there still remained 13 political groups and fractions ${ }^{17}$. Considerable changes took place in the parliament: parties and political groups were established and wound up, factions split up and were reorganized again. Further on, the circulation of the members from one faction to another is practically continuous. There were four major structural changes of the parliament during the period referred to; that,

15 Masol was Prime Minister from 28 June 1990 to 17 October 1994, and from 16 June 1994 to 6 March 1995, Janukovich 21 November 2002 - 7 December 2004, and from 4 of August 2006 to 23 August 2006. The name of Janukovich marks the few-day period between 28 December 2004 and 5 January 2005. Timosenko, the current Prime Minister of Ukraine was elected on 18 December 2007, after the crisis of the government he was prime minister before between 4 February and 8 September 2005. Nikolai Azarov was prime minister twice as temporary solution in the period of 7-28 December 2004 and 5-24 January 2005.

16 The new era in the Ukrainian Parliament started on 30 March 1990, this is the date when the first parliament of the independent Ukraine was elected. The first term started on 15 May 1990. The sixth term of the Verkhovna Rada has been on since 30 September 2007.

17 Five of the 13 factions (the communists, the Our Ukraine of president Viktor Juschenko, the (United) Social-democrat Party of Ukraine led by Yuri Zagorodnij, Yulia Tymoshenko Block, Ukrainian Socialist Party led by Aleksandr Moroz were present from the beginning of the period, since 2002. Three of them (National Party, Ukrainian National Party and the Party of the Ukrainian Entrepreneurs and Industrialists led by Anatoly Kinah) were founded in 2005, while the five youngest started to work at the turn of the years 2005-2006. After the election of 2006 four of the oldest factions got into the parliament again: the communists, Our Ukraine, Yulia Tymoshenko Block and Ukrainian Socialist Party. 
of course, did not leave the party structure as well as the members of the specific parties unchanged. ${ }^{18}$

For following the changes of the number of the political groups and factions the researchers introduced an index deviating between -1 and +1 , the negative values refer to the decrease of the number of the group, while the positive values refer to the increase of the group's size. Taking the end of the fourth term of the parliament and 13 factions the authors found that the number of the members of six groups increased, six decreased while the number of members of the Party of Reforms and Order did not change. The balance was positive for the Yulia Tymoshenko Block, the socialists, the Litvin Block, the Regions of Ukraine faction and two other parties considering themselves to be national. On the other hand, the Our Ukraine or the faction of social-democrats suffered losses. The motives of changes are explained in two different ways by the experts. Leaving a political group on the one hand may refer to the weak ideological identity and commitment of the MP, and this may be a signal of a proper adaptation strategy on the other.

Continuing the empirical analysis the authors underline that the communist, the socialist and the social-democratic factions possess the most developed structural autonomy, which means that they were the least concerned by such changes. In order to outline the position of the parties in the network of the parliament the authors introduce the expression 'centrality' which carries three different meanings. First, it refers to the direct and indirect connections with other political groups, second, its position as a hub in the network and third, it means also its mediator role. In other words, the first aspect is transit between the groups (structural units) which means the change of place of the members. The second aspect - in addition to those specified in the previous sentence shows the role of the 'acquaintance of the acquaintance' during the change. The third element refers to the transmitting function regarding the whole parliament.

If we take the second half of the period the year of 2005, the Yulia Tymoshenko Block was one of those in the central position. This central position was supported by the number of direct and indirect connections with other parties as well as the rate of the transmitting function. The authors agree that their key position is attributable to the common knowledge that Yulia Tymoshenko is to be named as candidate to the prime ministry. With the exception of the transmitting function the same can be noticed in case of the Party of the Regions. The faction of Our Ukraine has slightly lower indices of centrality compared to the two organizations referred to above. The authors - following the findings of Granovetter and Burt - disclosed the structural holes in the ego network, types thereof are the following: effectiveness of the relationships, limits, and hierarchy. As the scholars found the following parties have the most effective relationships: Our Ukraine, Communist Party, the Yulia Tymoshenko Block, the (United) Social-democratic Party and the Litvin National Block. The second indicator shows those limits that are formed by the small-figure relationship around the ego. By the findings of the research the most individual unit is the Our Ukraine, while the Yulia Tymoshenko Block showed a slight independence. The phenomenon called hierarchy is

18 They happened in: May-July 2002, August-September 2002, October 2004-August 2005 and September 2005-March 2006.

Review of Sociology 14 (2008) 
the case when the effectiveness of the network of a person is limited by another specific person. If the ego network has lots of relationships, that is a limitation to the ego then one may predict the lowest level of the hierarchy. In case there is such a strong relationship that practically blocks the operation of the individual network then the level of hierarchy approaches the highest level. According to the findings the networks of the socialists and the communists concentrate the least on one single faction; they are relatively 'free'. As we have seen it earlier these two parties have a high level of structural independence. The authors search those people who act like bridges between the different groups helping the integrity of the whole network by such activity. Among the known key players the following parties functioned as bridges: in the second term of the period For United Ukraine and Our Ukraine, in the third one the People's Party, in the fourth the Yulia Tymoshenko Block and the Block of the Regions of Ukraine.

The researchers underline the following general tendencies in the Ukrainian Parliament during the term of 2002-2006. First of all: the more considerable factions made up by different political forces are willing to split up by the features of the different parties. This was also the tendency regarding the split For United Ukraine as well as the previously opposition government party Our Ukraine. Second they found that the factions with clear ideology are less likely to be 'involved' in parliamentary relations, the number of the members in these factions is relatively consistent, in other words the number of change of the members is low. This result is confirmed by the fact that only one of the political groups formed based on common interest - and not on a common ideological base continued to work after the election of 2006: this was the Litvin National Block. Further on it was also found that the direct or indirect connection with these political groups may serve as a resource to the particular party: it increases the lobby possibilities of the given group. The Yulia Tymoshenko Block is a good example of this: with the help of its network resources it gained quite strong parliamentary support in the course of electing Yulia Tymoshenko as prime minister in February $2005 .{ }^{19}$ Finally, they state that the power of a parliamentary political group is measurable not only by the number of its relationships with other political groups, but also by the possibility of autonomous initiatives and acting as well as how they can avoid the networking control of the organization.

The article of Gorbachik and his co-author made the possibility to get an inside view into the life of the Ukrainian Parliament. This article is interesting both to the public and to the scholars. The authors successfully simplify that disturbingly vivid overview one may have on Verkhovna Rada at a first glance. All of this is made by them through applying the social network analysis. The term of 2002-2006 was very active in the Ukrainian Parliament: there were a total of 37 political groups, parties and factions in four years, the authors intended to follow and outline the structural changes, and they pointed out four important structural changes during this period. After making the balance of those representatives who changed from one faction to another in the parliament they emphasise that the socialists, the communists and the social democrats changed parties most rarely: they have the highest level of structural autonomy. The hands of the socialists and the communists are free, they are not bound by any strong relation; therefore they are relatively free to act. They pointed out that by the years of 
2005-2006 the Yulia Tymoshenko Block and the Party of the Regions of Ukraine moved toward a central position from their non-central one at the beginning of the term. The researchers have proper knowledge in using the method of social network analysis as well as its terms and techniques. Methodologically it is a nice solution, that the relationship between two political groups is operationalised as accessibility from one political group to another. They explain and use their definitions - as centrality or structural anatomy - accurately in an easy-to-follow manner.

\section{REFERENCES}

Fedinec Cs. (2007): Hatalmi játszmák Ukrajnában. Másfél évtized mérlege. [Power Games in Ukraine. Balance of Fifteen Years.] Kommentár, 3: 90-103.

Golovakha, Y. and Panina, N. (2006): Osnovnye yetapy i tendencii transformacii ukrainskovo obschestva: ot perestrojki do „oranzhevoj revolyucii”. [The Main Stages and Tendencies in the Transformation of Ukrainian Society: from Perestrojka to the „Orange Revolution”.] Sociologia: teoria, metody, marketing, 3: 32-51.

Gorbachik, A. and Zhulkevskaja, E. (2006): Setevoj podhog k izucheniu struktury ukrainskogo parlamenta. [Study of Ukrainian Parliament Structure by Means of Network Analysis.] Sociologia: teoria, metody, marketing, 3: 161-181.

Higley J. and Pakulski J. (1995): Elite Transformation in Central and Eastern Europe. Australian Journal of Political Science, 30:1-29.

Kullberg, J., Higley, J. and Pakulski, J. (1998): Elites, Institutions and Demokratization in Russia and Eastern Europe. In Kullberg, J., Higley, J. and Pakulski, J.: Elites and Leadership in Russian Politics. New York:Basingstoke, 107.

Lane, D. (2006): Yelity, klassy i grazhdanskoe obschestvo $\mathrm{v}$ period transformacii gosudarstvennovo socializma. [Elites, Classes and Civil Society in the Transformation of State Socialism.] Sociologia: teoria, metody, marketing, 3: 14-31.

Lane, D. and Ross, C. (1999): The Transition from Communism to Capitalism. Ruling Elites from Gorbachev to Yeltsin. New York: St. Martin's.

Ludvig Zs. (2006): Ukrajna újra választott? [Has Ukraina Elected Again?] Magyar Tudományos Akadémia Világgazdasági Kutatóintézet. Short Notice,125(április 20).

Ludvig Zs. (2007): Két kelet-európai választás: régi-új arcok - régi dilemmák? [Two East-European Elections: Old-New Faces - Old Dilemmas?] Short Notice, 153(December 20).

Ukraine Economic Update. January, 2008. World Bank:

http://siteresources.worldbank.org/UKRAINEEXTN/Resources/Macro_update_eng.pdf, Downloaded on April 5th, 2008.

http://www.interfax.com.ua/ru home page of Interfax Press Agency, downloaded in March-April, 2008.

www.karpatinfo.net, downloaded in April, 2007.

http://www.kommersant.ua/index.html political and economical newspaper, continuous downloads.

http://korrespondent.net/ukraine political and economical weekly, downloaded in March-April, 2008. http://www.mfa.gov.hu/kum/hu/bal/Kulpolitikank/Ketoldalu_kapcsolatok/Europa/ukrajna/gaz dasagikapcsolatok.htm Press Release of the Ministry of Foreign Affairs on Ukraine, downloaded on 5th of April, 2007.

www.rada.gov.ua official home page of Ukrajnai Verkhovna Rada, downloaded in March-April, 2008.

Review of Sociology 14 (2008) 